\title{
Performance Evaluation of Jatropha and Pongamia Oil Based Environmentally Friendly Cutting Fluids for Turning AA 6061
}

\author{
T. P. Jeevan $\mathbb{D}^{1,2}$ and S. R. Jayaram ${ }^{1,2}$ \\ ${ }^{1}$ Department of Mechanical Engineering, Malnad College of Engineering, Hassan 573201, India \\ ${ }^{2}$ Visvesvaraya Technological University, Belagavi, India \\ Correspondence should be addressed to T. P. Jeevan; jeevantpmce@gmail.com
}

Received 18 January 2018; Revised 29 March 2018; Accepted 16 April 2018; Published 15 May 2018

Academic Editor: Huseyin Çimenoğlu

Copyright (C 2018 T. P. Jeevan and S. R. Jayaram. This is an open access article distributed under the Creative Commons Attribution License, which permits unrestricted use, distribution, and reproduction in any medium, provided the original work is properly cited.

\begin{abstract}
Owing to the desirable properties of vegetable oils as cutting fluids, an attempt is made to explore the potentiality of plentifully available vegetable oils as a cutting fluid for turning AA 6061. Two nonedible vegetable oils, Jatropha and Pongamia, in their chemically modified (epoxidized) versions are used as straight cutting fluids. Cutting fluids are introduced to the machining zone with the aid of Minimal Quantity Lubrication (MQL) method. Taguchi's technique of orthogonal arrays is used to develop an effective design of experiments. The results obtained under epoxidized versions of Jatropha and Pongamia oils are compared with the results of mineral oil in terms of cutting forces and surface roughness. Experimental observations and statistical analysis show that, compared to mineral oil, the modified versions of vegetable oil-based cutting fluids are more effective in reducing the cutting forces and increasing surface finish. It is also observed that the modified Pongamia oil showed lesser flank wear compared to the other two tested oils.
\end{abstract}

\section{Introduction}

The application of cutting fluids in machining was first reported by F. Taylor in 1894 who observed that up to 33\% increase in cutting speed can be achieved without affecting the life of cutting tool by applying large amounts of water as cutting fluid to the machining zone. Cutting fluids are extensively used in the machining process to carry away heat generated at machining zone, lubricate and take away chips, and prevent corrosion during machining operations [1]. Cutting fluids results in improved tool life, work quality, effective chip management, and reduced process variability. Thus, utilization of cutting fluids is increasing in the metal cutting operations [2]. Major share of cutting fluids being used across the globe are petroleum-based oils. Enormous use of petroleum-based oils has had a lot of negative environmental and health-related consequences like skin diseases [3]. Petroleum-based lubricants in 2016 have increased tremendously on high global consumption, showing at least $1 \%$ annual increments with 13,726 million tons of oil equivalent [4]. This has therefore, made another viewpoint of bad impact on the environmental pollution and the danger of large loss proportion (13-50\%) of the lubricants in the aquatic and terrestrial ecosystems, including continuous depletion of global energy and natural resources, prevail [5]. The increasing consciousness for green manufacturing globally and consumer focus on environmentally friendly products has put increased pressure on industries to minimize the use of petroleum-based cutting fluids [6]. The demand for biodegradable and eco-friendly cutting fluids has opened an avenue for using vegetable oils as a potential alternative to petroleum-based cutting fluids [7]. In this regard, vegetable oils are emerging as potential replacements to conventional cutting fluids [8].

Vegetable oil-based cutting fluids are highly biodegradable, eco-friendly, renewable, less toxic, high flash point, low volatility, high viscosity index, wide production possibilities, and economical in the waste management [9-12]. Vegetable oils primarily consist of triglycerides; [13-15] the triglycerol structure of vegetable oil makes it a strong competitor as a base stock for lubricants and functional fluids [16]. Vegetable oils are triglycerides in which $\mathrm{C} 18$ carboxylic acids are dominant. Some of the fatty acids derived from these glycerides are unsaturated; those typically contain stearic, 

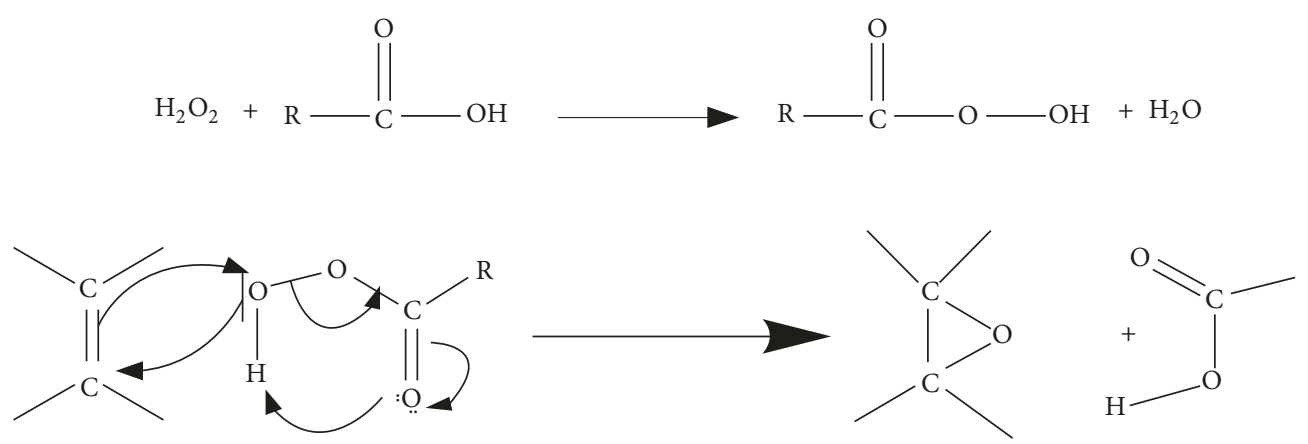

FIGURE 1: Mechanism of epoxidation reaction for vegetable oil [18].

oleic, linoleic, and linolenic acids in varying amounts. Three of these are unsaturated acids, namely, oleic $(18: 1)$, linoleic $(18: 2)$, and linolenic $(18: 3)$.

The use of edible vegetable oil to produce lubricants and cutting fluids is not feasible in view of the big gap in demand and supply of such oil. Hence, nonedible vegetable oils are finding importance due to their abundance and also, this would save large quantities of edible oils which are in great demand. The forecast for eco-friendly lubricants for next $10-15$ years is a worldwide volume share of approximately $15 \%$ and in some regions up to $30 \%$ [17].

Many metal cutting processes are tested by researchers to employ the vegetable oil-based fluids as metal cutting oils and observed a better performance. The Jatropha oil proved to be the best one for being used in the machining AA7050-T7451 [19]. The coconut oil is impressive in reducing surface roughness at higher values of feed and depth of cut while turning hardened AISI 52100 [20] and also showed an improved tool life for turning of AISI 304 [21]. The significant reduction in tool wear, cutting force, better dimensional accuracy, and surface roughness by MQL and a favourable change in chip tool and work tool interaction are observed while turning AISI 1060 [22] and AISI 4340 [23] steel using vegetable oils. The reduction in coefficient of friction is observed while machining mild steel, brass, and aluminum under different cutting conditions using Palm kernel oil as cutting fluid [24]. A formulated cutting fluid of Canola with $8 \%$ extreme pressure additive showed lower turning forces, tool wear, and surface roughness values for turning AISI 304L [25]. Sunflower and Canola oil based cutting fluids [26] generate better surface finish and produce lower cutting and feed forces while turning AISI $304 \mathrm{~L}$. A novel cutting fluid was developed from nonedible Neem [27] performed better with respect to temperature rise at tip, cutting forces, tool wear, and surface roughness. The modified Jatropha oil [11] showed the lowest values of cutting force, cutting temperature, and surface roughness, with a prolonged tool life and less tool wear. Coconut oil with $0.5 \%$ nanoparticle inclusions resulted in improved machining performance compared to Sesame oil and Canola oil [28]. The demand for a balance in meeting both the technological and environmental requirements of a new cutting fluid for machining process forms the basis of this research. In this regard, nonedible vegetable oil modified Jatropha (MJO) and modified Pongamia (MPO) are experimentally investigated and compared with mineral oil (MO) based on Taguchi's design of experiments, for their sustainability as metal cutting fluids during turning AA6061, using minimum quantity lubrication technique (MQL). MQL has proven to be a better alternative to a flood coolant system in which a mixture of air and cutting fluid is applied to the cutting zone. It has a better reach ability as a result of the high pressure [29].

\section{Materials and Methods}

2.1. Formulation of the Vegetable Oil-Based Cutting Fluids. Biofuels have already been accepted around the world for their advantages over conventional petroleum fuels, including the opportunity for energy independency. Now, similar growth is expected for biolubricants, which are derived from renewable vegetable oils for different applications [30]. Jatropha and Pongamia based cutting fluids have a huge potential owing to their abundant availability, renewability, and biodegradability. However, the challenges with these oils in meeting lubricant performance is their low oxidative stability [31]; they cannot be used in their raw form. Hence, they are chemically modified by the process of epoxidation. Epoxidation of fatty acids is a reaction of a carbon-carbon double bond with active oxygen, which results in the addition of an oxygen atom, converting the original double bond into a three membered epoxide (oxirane) ring (Figure 1). In epoxidation process a known volume of oil is blended with formic/acetic acid and hydrogen peroxide. The reaction takes place for 14 hours, with 7 hours of titration in the presence of formic acid and hydrogen peroxide and 7 hours of constant agitation in the temperature range of $50^{\circ} \mathrm{C}$ to $60^{\circ} \mathrm{C}$, thus removing double bonds in the fatty acid chain of the oil. Epoxidized vegetable oil produces flexibility and elasticity due to the presence of the epoxy ring in the backbone chain [32]. The changes in the properties of vegetable oil after chemical modification can be identified in Table 1 . The iodine value of oil confirms the process of epoxidation.

2.2. Experimental Design by Taguchi Technique and Machining Conditions. In this study, AA 6061 having a Vickers hardness of 107 was used as a workpiece material, which had a dimension of $\varnothing 45 \mathrm{~mm} \times 200 \mathrm{~mm}$. The measured values of chemical composition of AA 6061 in percentage of weight 
TABLE 1: Physicochemical properties of vegetable oils, their modified versions, and mineral oil.

\begin{tabular}{lccc}
\hline Properties & MJO & MPO & MO \\
\hline Kinematic viscosity @ $40^{\circ} \mathrm{C}(\mathrm{cSt})$ & 11.22 & 20.15 & 33.00 \\
Viscosity index & 225.36 & 219.00 & 185.21 \\
Saponification value $\left(\mathrm{mg} \mathrm{KOH} \mathrm{g}^{-1}\right)$ & 203.80 & 198.00 & - \\
Total acid value $\left(\mathrm{mg} \mathrm{KOH} \mathrm{g}^{-1}\right)$ & 00.05 & 0.13 & 01.75 \\
Flash point $\left(0^{\circ} \mathrm{C}\right)$ & 180.00 & 190.00 & 160.00 \\
Pour point $\left(0^{\circ} \mathrm{C}\right)$ & -03.00 & -02.00 & -7.00 \\
Iodine value $\left(\mathrm{mg} \mathrm{lg}^{-1}\right)$ & 22.00 & 21.41 & 6.50 \\
\hline
\end{tabular}

TABLE 2: Compositions of AA6061.

\begin{tabular}{lccccccccc}
\hline Contents & $\mathrm{Cu}$ & $\mathrm{Mg}$ & $\mathrm{Si}$ & $\mathrm{Fe}$ & $\mathrm{Mn}$ & $\mathrm{Ti}$ & $\mathrm{Zn}$ & $\mathrm{Cr}$ & $\mathrm{Al}$ \\
\hline \% of weight & 0.263 & 0.902 & 0.403 & 0.135 & 0.076 & 0.022 & 0.011 & 0.153 & Remaining \\
\hline
\end{tabular}

TABLE 3: Machining conditions.

\begin{tabular}{lc}
\hline Machine & Engine lathe-LB-20 \\
Work piece material & AA 6061 \\
Process parameters & \\
Spindle speed (rpm) & 800,1270 , and 1600 \\
Feed (mm/rev) & $0.100,0.175$, and 0.250 \\
Depth of cut (mm) & $0.5,1.0$, and 1.5 \\
Cutting tool & \\
Material & Carbide cutting tool (uncoated) \\
Tool holder & High speed steel (HSS) \\
Tool nose radius (mm) & 0.4 \\
Cutting tool edge length (mm) & 9 \\
Cutting fluids & MJO, MPO, and MO \\
Cutting fluid supply & MQL method (3 to 4 bars) \\
\hline
\end{tabular}

are given in Table 2. The machining parameters as per the recommendations from the tool manufacturer are selected. Spindle speed, feed, depth of cut, and type of cutting fluid are considered as machining parameters. The type of cutting fluid used is considered as one of the demanding input parameters while designing the experiments. Accordingly, four input parameters (the type of cutting fluid, spindle speed, feed rate, and depth of cut), and for each parameter three levels, were assumed (Table 3). For four factors, threelevel experiments, Taguchi had specified L27 orthogonal array for experimentation. The data obtained from the trials conducted as per L27 array experimentation was recorded and further analyzed. Table 3 shows the parameters and their levels considered for the experiments. The experimental setup is shown in Figure 2.

2.3. Cutting Force and Surface Roughness Measurement. The cutting force influences the deformation of the machined work piece, its dimensional accuracy, chip formation, tool wear, surface roughness, and stability of the machining system. Machining parameters affecting cutting forces include depth of cut, cutting speed, and type of cutting fluid. Hence, the study of cutting force as a quality characteristic and the influence of cutting fluid on the cutting force is

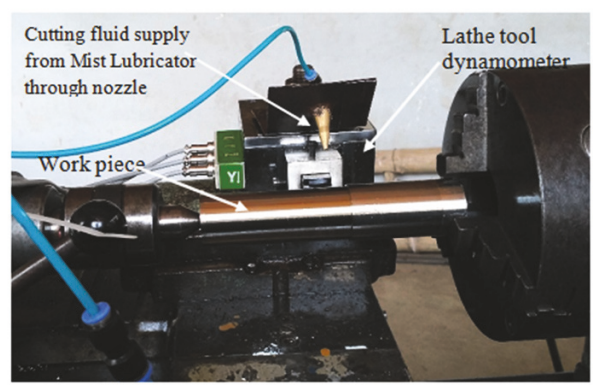

FIGURE 2: Experimental setup.

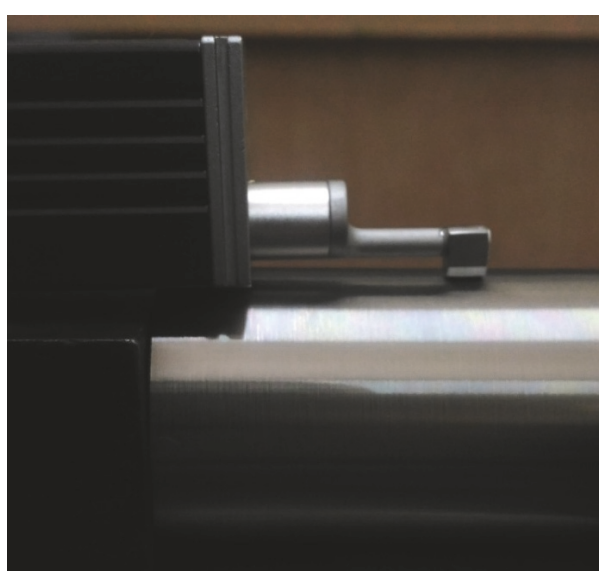

FIGURE 3: Measuring surface roughnesses with stylus on workpiece.

important. The cutting force generated during machining is measured with a strain gauge type lathe tool dynamometer at different speeds and feeds under modified vegetable oilbased cutting fluids. Surface roughness is a significant design specification that is known to have considerable influence on properties such as wear resistance and fatigue strength. Surface roughness $\left(R_{a}\right)$ of the machined surface is measured with a SURFCOM FLEX-50. The surface roughness values are measured by moving the stylus along the axis of turned workpiece over the machined surface as shown in Figure 3. 
TABLE 4: Cutting force and surface roughness for interfamily comparison.

\begin{tabular}{|c|c|c|c|c|c|c|}
\hline $\begin{array}{l}\text { Trial } \\
\text { number }\end{array}$ & Cutting fluids & $\begin{array}{c}\text { Depths of cut } \\
(\mathrm{mm})\end{array}$ & $\begin{array}{l}\text { Feed rates } \\
(\mathrm{mm} / \mathrm{rev})\end{array}$ & $\begin{array}{c}\begin{array}{c}\text { Spindle speeds } \\
(\mathrm{rpm})\end{array} \\
\end{array}$ & Cutting force $(\mathrm{N})$ & $\begin{array}{c}\text { Surface roughness } \\
(\mu \mathrm{m})\end{array}$ \\
\hline 1 & MJO & 0.5 & 0.100 & 0800 & 75 & 0.8 \\
\hline 2 & MJO & 0.5 & 0.175 & 1270 & 105 & 0.9 \\
\hline 3 & MJO & 0.5 & 0.250 & 1600 & 80 & 1.4 \\
\hline 4 & MJO & 1.0 & 0.100 & 1270 & 145 & 0.7667 \\
\hline 5 & MJO & 1.0 & 0.175 & 1600 & 215 & 0.8333 \\
\hline 6 & MJO & 1.0 & 0.250 & 0800 & 345 & 1.3667 \\
\hline 7 & MJO & 1.5 & 0.100 & 1600 & 200 & 0.7333 \\
\hline 8 & MJO & 1.5 & 0.175 & 0800 & 350 & 1.2 \\
\hline 9 & MJO & 1.5 & 0.250 & 1270 & 435 & 1 \\
\hline 10 & MPO & 0.5 & 0.100 & 0800 & 70 & 0.8 \\
\hline 11 & MPO & 0.5 & 0.175 & 1270 & 100 & 0.8 \\
\hline 12 & MPO & 0.5 & 0.250 & 1600 & 145 & 1.6 \\
\hline 13 & MPO & 1.0 & 0.100 & 1270 & 140 & 0.8 \\
\hline 14 & MPO & 1.0 & 0.175 & 1600 & 235 & 1 \\
\hline 15 & MPO & 1.0 & 0.250 & 0800 & 330 & 1.1 \\
\hline 16 & MPO & 1.5 & 0.100 & 1600 & 215 & 0.8 \\
\hline 17 & MPO & 1.5 & 0.175 & 0800 & 365 & 1 \\
\hline 18 & MPO & 1.5 & 0.250 & 1270 & 420 & 1.4 \\
\hline 19 & $\mathrm{MO}$ & 0.5 & 0.100 & 0800 & 75 & 1.033 \\
\hline 20 & $\mathrm{MO}$ & 0.5 & 0.175 & 1270 & 110 & 1.1 \\
\hline 21 & MO & 0.5 & 0.250 & 1600 & 145 & 1.6 \\
\hline 22 & $\mathrm{MO}$ & 1.0 & 0.100 & 1270 & 155 & 0.7 \\
\hline 23 & $\mathrm{MO}$ & 1.0 & 0.175 & 1600 & 230 & 1 \\
\hline 24 & $\mathrm{MO}$ & 1.0 & 0.250 & 0800 & 340 & 1.5 \\
\hline 25 & MO & 1.5 & 0.100 & 1600 & 210 & 1.1 \\
\hline 26 & MO & 1.5 & 0.175 & 0800 & 345 & 1.2 \\
\hline 27 & $\mathrm{MO}$ & 1.5 & 0.250 & 1270 & 315 & 1.4 \\
\hline
\end{tabular}

2.4. Tool Wear Measurement. Tool wear was measured using educational optics transverse microscope which is modified into Tool Maker's Microscope having least count of $1 \mu \mathrm{m}$. Tool inserts were withdrawn after each continuous cut and were studied under Tool Maker's Microscope for the wear pattern and width of the flank wear. Flank wear most commonly results from abrasive wear of the cutting edge against the machined surface. Flank wear is measured in terms of average wear land size $V_{B}$.

\section{Results and Discussion}

Experimentally determined values of cutting force and surface roughness values (Table 4) are used to investigate the performance of vegetable based cutting fluids. Statistical analyses of experimental results obtained are carried out using MINITAB 17; statistical package established on Taguchi's principle is used for analysis.

3.1. Analysis of $S / N$ and ANOVA. The statistical analysis is carried out to find the process parameters which extremely affect the quality characteristics (cutting force and surface roughness) and to identify the favourable level of each process parameter which results in the least cutting force and surface roughness.

The $\mathrm{S} / \mathrm{N}$ ratio values for cutting force and surface roughness are obtained using the equation shown below and, for optimizing the process in this study, the smaller the $\mathrm{S} / \mathrm{N}(\mathrm{dB})$ ratio, the better the characteristic.

$$
\frac{\mathrm{S}}{\mathrm{N}}=-10 \log _{10}\left[\frac{1}{n} \sum_{i=1}^{n} y_{i}^{2}\right],
$$

where $n$ is the number of measurements in a trial/row and $y i$ is the $i$ th measured value in a run. It includes the effect of noise as well.

From the $\mathrm{S} / \mathrm{N}$ ratio analysis (Figure 4), optimal turning parameters for the cutting force are $0.5 \mathrm{~mm}$ of depth of cut, $0.1 \mathrm{~mm} / \mathrm{rev}$ of feed rate, and $1600 \mathrm{rpm}$ of spindle speed. MJO performed optimally followed by MPO and MO. The optimal turning parameters for surface roughness as obtained from main effect plot of the $\mathrm{S} / \mathrm{N}$ ratio (Figure 5) are found to be $1.5 \mathrm{~mm}$ of depth of cut, $0.175 \mathrm{~mm} / \mathrm{rev}$ of feed rate, and $800 \mathrm{rpm}$ of spindle speed. MPO performed optimally in 


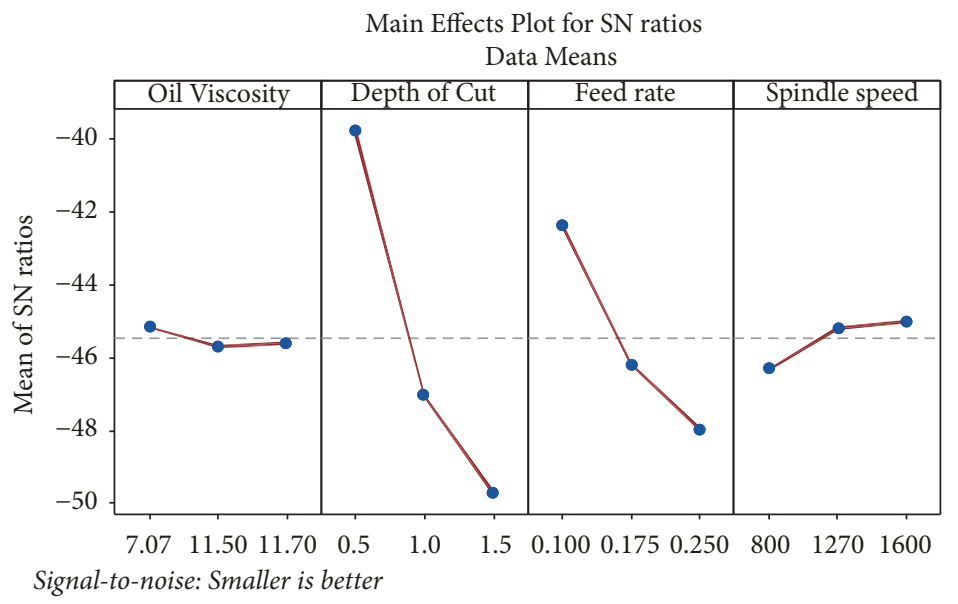

FIGURE 4: Main effects plot for cutting force.

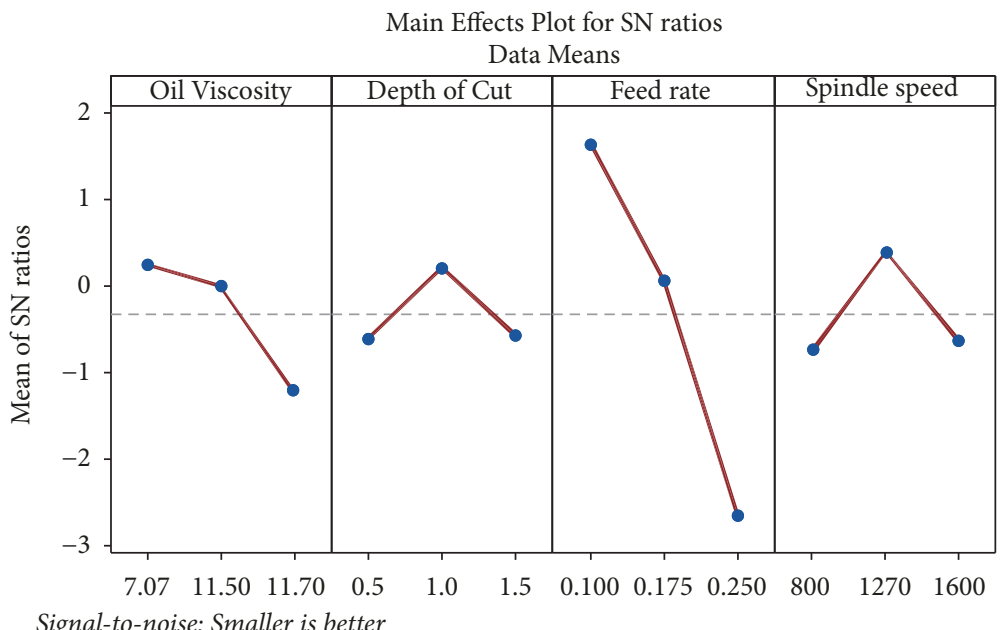

FIGURE 5: Main effects plot for surface roughness.

improving the machined surface quality followed by MJO and MO. Hence, both vegetable oil-based cutting fluids performed well compared to mineral oil with respect to cutting force and surface roughness. The lower cutting forces of vegetable oils can be attributed to better lubricity, higher viscosity index, and better thermal conductivity compared to mineral oils. This is because the modified version has more resistance to molecular breakdown, or a molecular rearrangement at a higher temperature, due to which the presence or absence of oxygen molecules was improved [7]. Previous studies also confirmed that, chemically modified vegetable oil exhibited better lubrication ability and stronger adsorption film onto metallic surface [33]. The better performance with respect to surface roughness is due to the fact that the longer carbon chains of vegetable oil corresponded to a stronger adsorption film which enhanced the surface quality [34].

The effect of viscosity, speed, and feed on response parameters, that is, cutting force and surface roughness, is measured using ANOVA. From Tables 5 and 6 it is observed that cutting fluid, speed, depth of cut, and feed rate influence the cutting force by $0.1 \%, 5 \%, 63 \%$, and $28 \%$, respectively. Effects of cutting fluid, speed, depth of cut, and feed rate on surface roughness is found to be $10.65 \%, 5.73 \%, 4.13 \%$, and $61.68 \%$, respectively.

3.2. Regression Analysis. Multiple regression analysis on the obtained data is done using Minitab 17. The independent variables are viscosity of cutting fluids, spindle speeds, feed rates, and depths of cut. The dependent variables are cutting force and surface roughness. Separate regression models are built for predicting cutting force and surface roughness. The regression equations obtained are

$$
\begin{aligned}
F_{c}= & -62.2905+0.474026 \text { Viscosity }+216.66 \text { Depth } \\
& +940.741 \text { Feed }-0.08620 \text { Speed } \\
R_{a}= & 0.12240+0.034549 \text { Viscosity }-0.1036 \text { Depth } \\
& +3.531 \text { Feed }+5.844 \mathrm{e}-005 \text { Speed. }
\end{aligned}
$$


TABLE 5: ANOVA interfamily cutting force.

\begin{tabular}{lccc}
\hline Source of variance & DOF & Sum of squares & \% contribution \\
\hline Viscosity & 2 & 363 & 0.098066 \\
Depth & 2 & 235524 & 63.62814 \\
Feed & 2 & 104080 & 28.1178 \\
Speed & 2 & 21446 & 5.793758 \\
Viscosity $*$ Depth & 4 & 837 & 02.999 \\
Viscosity $*$ Feed & 4 & 131 & 0.22612 \\
Viscosity $*$ Speed & 4 & 1781 & 0.03539 \\
Error & 6 & 5994 & 370157 \\
Total & 26 & & \\
\hline
\end{tabular}

TABLE 6: ANOVA interfamily surface roughness.

\begin{tabular}{lccc}
\hline Source of variance & DOF & Sum of squares & \% contribution \\
\hline Viscosity & 2 & 0.23704 & 10.658 \\
Depth & 2 & 0.09188 & 04.131 \\
Feed & 2 & 1.37208 & 61.683 \\
Speed & 2 & 0.12748 & 05.732 \\
Viscosity $*$ Depth & 4 & 0.12314 & 05.537 \\
Viscosity $*$ Feed & 4 & 0.00981 & 00.441 \\
Viscosity $*$ Speed & 4 & 0.04754 & 02.1375 \\
Error & 6 & 0.21509 & 2.22405 \\
Total & 26 & & \\
\hline
\end{tabular}

$R$-Sq values for cutting force and surface roughness are $93 \%$ and $78 \%$, respectively, where $R-S q$ is correlation coefficient and should be between 0.8 and 1 in multiple linear regression analyses [35]. It provides a correlation between the experimental and predicted results. The comparisons of actual and predicted values of the observed parameters, that is, cutting force and surface roughness, from the regression models are depicted in Figures 6 and 7. And it is seen that the cutting force and surface roughness observed experimentally and the predicted values by the regression models built are close.

The confirmation tests are conducted for that particular run. Using the regression model, the values of cutting force and surface roughness are predicted for randomly chosen trials. The results of confirmation experiments in Tables 7 and 8 show the difference between the predicted values and actual values. For reliable statistical analyses, error values must be smaller than $20 \%$. The values of both the sets are compared and percentage errors are calculated. The maximum error of $11.39 \%$ is observed which is found within an acceptable range.

3.3. Tool Wear Behaviour. It is observed that modified Pongamia oil showed lesser tool wear $(264.59 \mu \mathrm{m})$ for selected cutting parameters followed by mineral oil $(558.15 \mu \mathrm{m})$ and modified Jatropha oil $(577.51 \mu \mathrm{m})$. Figure 8 shows SEM images of tool flank wear for different oil samples. From Figures 8 (a) and 8 (b) it is clearly visible that wear of cutting tool is due to abrasion between tool and workpiece in the presence of vegetable oil as cutting fluids. In Figure 8(c), attrition or peeling away of the carbide insert is observed for mineral oil based cutting fluid. The chemical modification processes significantly increase the polar functionality of vegetable oils. The interactions between ester chains in both Jatropha and Pongamia molecules became stronger, hence increasing the adsorption potential on the metal surface. Thus, tool wear in modified versions of vegetable oils was reduced due to the polar structure of oil samples by forming a protective layer at the contact surfaces that reduced wear and friction [36].

\section{Conclusion}

The analysis of results by statistical approach based on Taguchi technique shows that the force developed during turning AA6061is said to be optimum for $0.1 \mathrm{~mm} / \mathrm{rev}$ of feed rate, for $0.5 \mathrm{~mm}$ of depth of cut, and at $1600 \mathrm{rpm}$ of speed in the presence of MJO as cutting fluid. A good surface finish is observed for MPO as cutting fluid at low speeds and MJO as cutting fluid at high speeds. Regression analysis showed that the percentage error for experimental and predicted values of cutting force and surface roughness are within an acceptable range. Thus, the modified versions of Pongamia and Jatropha oil as straight cutting fluids have a great potential for use as environmentally friendly and biodegradable metal cutting fluids. 


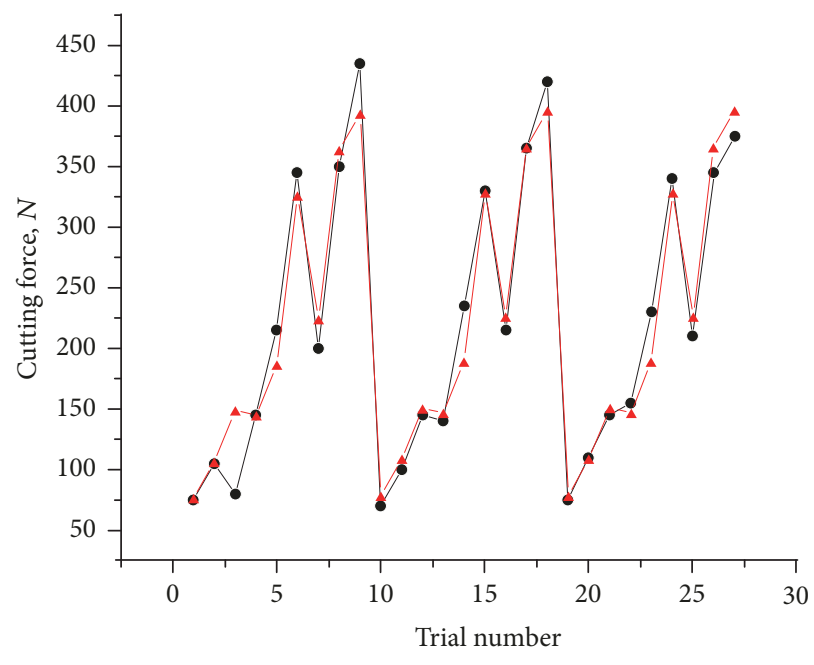

-- Actual Cutting force

-₫- Predicted Cutting force

Figure 6: Actual and predicted values of cutting force.

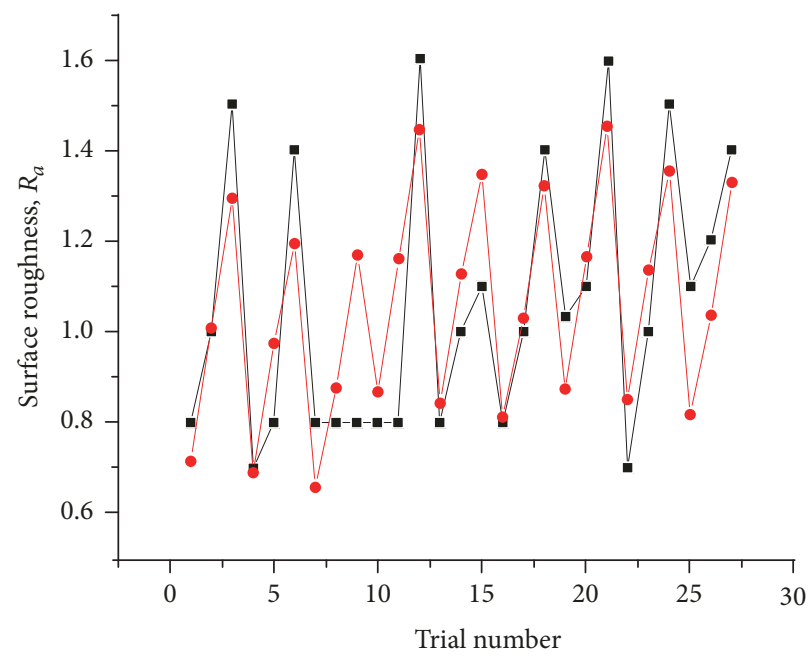

- - Actual surface roughness

- $\bullet$ Predicted surface roughness

FIGURE 7: Actual and predicted values of surface roughness.

TABLE 7: Confirmation tests for cutting forces.

\begin{tabular}{|c|c|c|c|c|c|c|}
\hline Cutting fluids & $\begin{array}{l}\text { Depths of cut } \\
(\mathrm{mm})\end{array}$ & $\begin{array}{l}\text { Feed rates } \\
(\mathrm{mm} / \mathrm{rev})\end{array}$ & $\begin{array}{l}\text { Speed } \\
(\mathrm{rpm})\end{array}$ & $\begin{array}{l}\text { Predicted force } F_{c} \\
(\mathrm{~N})\end{array}$ & $\begin{array}{l}\text { Experimental } \\
\text { force, } F_{c}(\mathrm{~N})\end{array}$ & $\%$ error \\
\hline MJO & 1 & 0.175 & 800 & 253.39 & 235 & 7.821 \\
\hline MPO & 0.5 & 0.175 & 1270 & 106.64 & 100 & 6.645 \\
\hline MO & 1.5 & 0.25 & 800 & 434.47 & 465 & 6.563 \\
\hline
\end{tabular}

TABLE 8: Confirmation tests for surface roughness.

\begin{tabular}{|c|c|c|c|c|c|c|}
\hline Cutting fluids & $\begin{array}{l}\text { Depths of cut } \\
(\mathrm{mm})\end{array}$ & $\begin{array}{l}\text { Feed rates } \\
(\mathrm{mm} / \mathrm{rev})\end{array}$ & $\begin{array}{l}\text { Speed } \\
(\mathrm{rpm})\end{array}$ & $\begin{array}{c}\text { Predicted } \\
R_{a}(\mu \mathrm{m})\end{array}$ & $\begin{array}{c}\text { Experimental } R_{a} \\
(\mu \mathrm{m})\end{array}$ & $\%$ error \\
\hline $\mathrm{MJO}$ & 0.5 & 0.1 & 1600 & 0.761 & 0.8 & 4.8186 \\
\hline MPO & 1 & 0.25 & 800 & 1.345 & 1.3 & 3.5065 \\
\hline MO & 1.5 & 0.175 & 1270 & 1.063296 & 1.2 & 11.392 \\
\hline
\end{tabular}




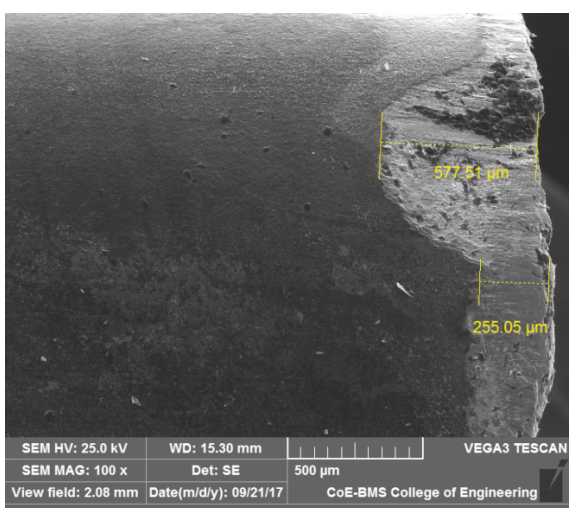

(a) Jatropha

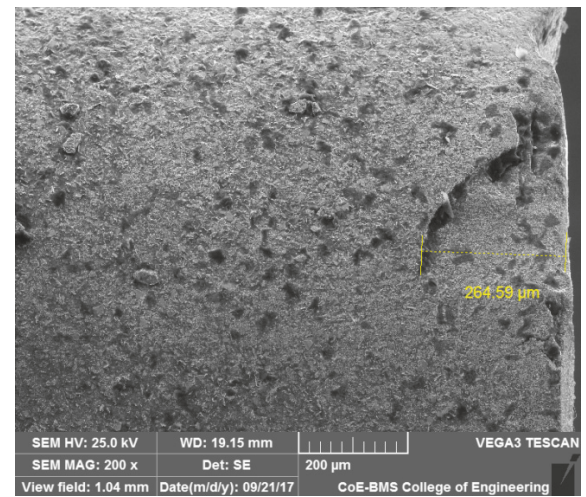

(b) Pongamia

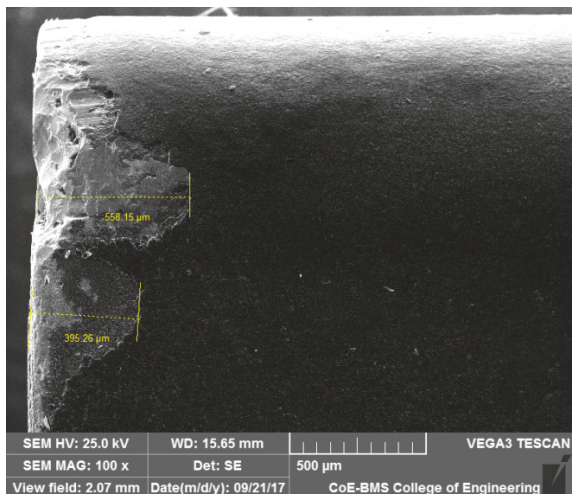

(c) Mineral oil

Figure 8: SEM images for flank wear.

\section{Data Availability}

The data used to support the findings of this study are available from the corresponding author upon request.

\section{Conflicts of Interest}

The authors declare that they have no conflicts of interest.

\section{References}

[1] K. K. Gajrani and M. R. Sankar, "Past and current status of ecofriendly vegetable oil based metal cutting fluids," Materials Today: Proceedings, vol. 4, no. 2, pp. 3786-3795, 2017.

[2] G. Burton, C.-S. Goo, Y. Zhang, and M. B. G. Jun, "Use of vegetable oil in water emulsion achieved through ultrasonic atomization as cutting fluids in micro-milling," Journal of Manufacturing Processes, vol. 16, no. 3, pp. 405-413, 2014.

[3] R. Somashekaraiah, P. S. Suvin, D. P. Gnanadhas, S. V. Kailas, and D. Chakravortty, "Eco-friendly, non-toxic cutting fluid for sustainable manufacturing and machining processes," Tribology Online, vol. 11, no. 5, pp. 556-567, 2016.

[4] British Petroleum. BP statistical review of world energy june 2017. 2017. p. 48.

[5] S. Amiril, E. Rahim, Z. Embong, and S. Syahrullail, "Tribological investigations on the application of oil-miscible ionic liquids additives in modified Jatropha-based metalworking fluid," Tribology International, vol. 120, pp. 520-534, 2018.
[6] P. Rapeti, V. K. Pasam, K. M. Rao Gurram, and R. S. Revuru, "Performance evaluation of vegetable oil based nano cutting fluids in machining using grey relational analysis-A step towards sustainable manufacturing," Journal of Cleaner Production, vol. 172, pp. 2862-2875, 2016.

[7] Y. M. Shashidhara and S. R. Jayaram, "Experimental determination of cutting power for turning and material removal rate for drilling of AA 6061-T6 using vegetable oils as cutting fluid," Advances in Tribology, vol. 2013, Article ID 362931, 7 pages, 2013.

[8] Y. M. Shashidhara and S. R. Jayaram, "Vegetable oils as a potential cutting fluid-An evolution," Tribology International, vol. 43, no. 5-6, pp. 1073-1081, 2010.

[9] J. K. Mannekote, S. V. Kailas, K. Venkatesh, and N. Kathyayini, "Environmentally friendly functional fluids from renewable and sustainable sources-A review," Renewable \& Sustainable Energy Reviews, vol. 81, pp. 1787-1801, 2018.

[10] Y. Singh, A. K. Singh, A. Singla, and A. K. Upadhyay, "Development and tribological characteristics of bio-based lubricant from Jatropha curcas oil," Energy Sources, Part A: Recovery, Utilization, and Environmental Effects, vol. 39, no. 16, pp. 17251732, 2017.

[11] N. Talib and E. A. Rahim, "Performance of modified jatropha oil in combination with hexagonal boron nitride particles as a biobased lubricant for green machining," Tribology International, vol. 118, pp. 89-104, 2018.

[12] J. Sharma and B. S. Sidhu, "Investigation of effects of dry and near dry machining on AISI D2 steel using vegetable oil," Journal of Cleaner Production, vol. 66, pp. 619-623, 2014. 
[13] B. Wilson, "Lubricants and functional fluids from renewable sources," Industrial Lubrication and Tribology, vol. 50, no. 1, pp. 6-15, 1998.

[14] N. J. Fox and G. W. Stachowiak, "Vegetable oil-based lubricantsA review of oxidation," Tribology International, vol. 40, no. 7, pp. 1035-1046, 2007.

[15] E. Kuram, B. Ozcelik, and E. Demirbas, "Environmentally Friendly Machining: Vegetable Based Cutting Fluids," in Green Manufacturing Processes and Systems, Materials Forming, Machining and Tribology, pp. 23-47, Springer Berlin Heidelberg, Berlin, Heidelberg, 2013.

[16] E. A. Rahim and H. Sasahara, "A study of the effect of palm oil as MQL lubricant on high speed drilling of titanium alloys," Tribology International, vol. 44, no. 3, pp. 309-317, 2011.

[17] P. Nagendramma and S. Kaul, "Development of ecofriendly/ biodegradable lubricants: An overview," Renewable \& Sustainable Energy Reviews, vol. 16, no. 1, pp. 764-774, 2012.

[18] Z. S. Petrović, A. Zlatanić, C. C. Lava, and S. Sinadinović-Fišer, "Epoxidation of soybean oil in toluene with peroxoacetic and peroxoformic acids - kinetics and side reactions," European Journal of Lipid Science and Technology, vol. 104, no. 5, pp. 293299, 2002.

[19] C. A. S. Bork, J. F. D. S. Gonçalves, J. D. O. Gomes, and J. Gheller, "Performance of the jatropha vegetable-base soluble cutting oil as a renewable source in the aluminum alloy 7050T7451 milling," CIRP Journal of Manufacturing Science and Technology, vol. 7, no. 3, pp. 210-221, 2014.

[20] S. Chinchanikar, A. Salve, P. Netake, A. More, S. Kendre, and R. Kumar, "Comparative Evaluations of Surface Roughness During Hard Turning under Dry and with Water-based and Vegetable Oil-based Cutting Fluids," Procedia Materials Science, vol. 5, pp. 1966-1975, 2014.

[21] M. A. Xavior and M. Adithan, "Determining the influence of cutting fluids on tool wear and surface roughness during turning of AISI 304 austenitic stainless steel," Journal of Materials Processing Technology, vol. 209, no. 2, pp. 900-909, 2009.

[22] M. M. A. Khan and N. R. Dhar, "Performance evaluation of minimum quantity lubrication by vegetable oil in terms of cutting force, cutting zone temperature, tool wear, job dimension and surface finish in turning AISI-1060 steel," Journal of Zhejiang University SCIENCE A, vol. 7, no. 11, pp. 1790-1799, 2006.

[23] S. A. Lawal, I. A. Choudhury, and Y. Nukman, "Evaluation of vegetable and mineral oil-in-water emulsion cutting fluids in turning AISI 4340 steel with coated carbide tools," Journal of Cleaner Production, vol. 66, pp. 610-618, 2014.

[24] S. J. Ojolo and O. S. Ohunakin, "Study of rake face action on cutting using palm-kernel oil as lubricant," Journal of Emerging Trends in Engineering and Applied Sciences (JETEAS), vol. 2, no. 1, pp. 30-35, 2011.

[25] B. Ozcelik, E. Kuram, M. Huseyin Cetin, and E. Demirbas, "Experimental investigations of vegetable based cutting fluids with extreme pressure during turning of AISI 304L," Tribology International, vol. 44, no. 12, pp. 1864-1871, 2011.

[26] M. H. Cetin, B. Ozcelik, E. Kuram, and E. Demirbas, "Evaluation of vegetable based cutting fluids with extreme pressure and cutting parameters in turning of AISI 304L by Taguchi method," Journal of Cleaner Production, vol. 19, no. 17-18, pp. 2049-2056, 2011.

[27] R. Katna, K. Singh, N. Agrawal, and S. Jain, "Green manufacturing-performance of a biodegradable cutting fluid," Materials and Manufacturing Processes, vol. 32, no. 13, pp. 1522-1527, 2017.
[28] P. Rapeti, V. K. Pasam, K. M. Rao Gurram, and R. S. Revuru, "Performance evaluation of vegetable oil based nano cutting fluids in machining using grey relational analysis-A step towards sustainable manufacturing," Journal of Cleaner Production, vol. 172, pp. 2862-2875, 2018.

[29] V. S. Sharma, G. Singh, and K. Sorby, "A review on minimum quantity lubrication for machining processes," Materials and Manufacturing Processes, vol. 30, no. 8, pp. 935-953, 2015.

[30] E. K. Heikal, M. S. Elmelawy, S. A. Khalil, and N. M. Elbasuny, "Manufacturing of environment friendly biolubricants from vegetable oils," Egyptian Journal of Petroleum, vol. 26, no. 1, pp. 53-59, 2017.

[31] Y. M. Shashidhara and S. R. Jayaram, "Tribological studies on AISI 1040 with raw and modified versions of pongam and jatropha vegetable oils as lubricants," Advances in Tribology, Article ID 560175, 2012.

[32] T. Saurabh, M. Patnaik, S. L. Bhagt, and V. C. Renge, "Epoxidation of vegetable oils: a review," International Journal of Advanced Engineering Technology, vol. 2, no. 4, pp. 491-501, 2011.

[33] J. Salimon, B. M. Abdullah, R. M. Yusop, and N. Salih, "Synthesis, reactivity and application studies for different biolubricants," Chemistry Central Journal, vol. 8, no. 1, article no. 16, 2014.

[34] B. Li, C. Li, Y. Zhang, Y. Wang, D. Jia, and M. Yang, "Grinding temperature and energy ratio coefficient in MQL grinding of high-temperature nickel-base alloy by using different vegetable oils as base oil," Chinese Journal of Aeronautics, vol. 29, no. 4, pp. 1084-1095, 2016.

[35] D. C. Montgomery, Design and Analysis of Experiments, John Wiley \& Sons, 5th edition, 2001.

[36] Y. Zhang, C. Li, D. Jia, D. Zhang, and X. Zhang, "Experimental evaluation of MoS2 nanoparticles in jet MQL grinding with different types of vegetable oil as base oil," Journal of Cleaner Production, vol. 87, no. 1, pp. 930-940, 2015. 


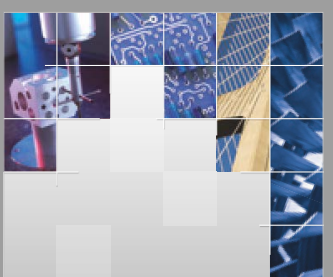

\section{Enfincering}
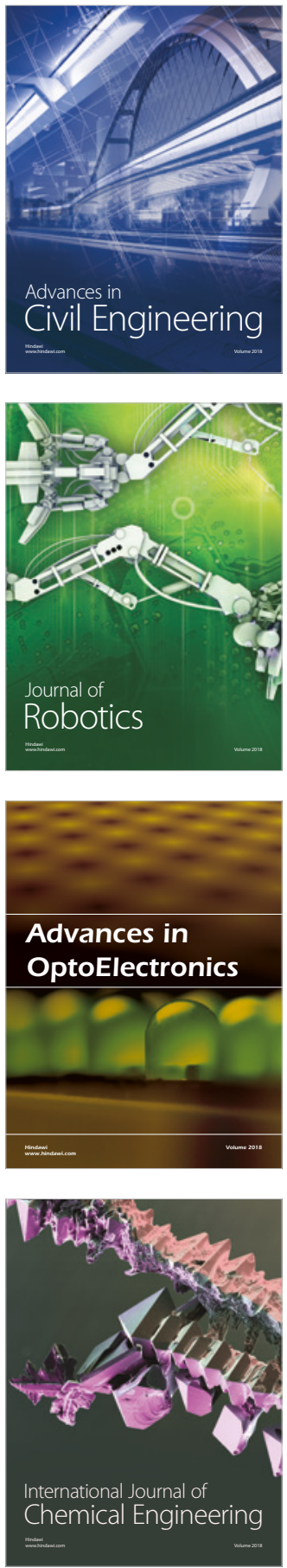

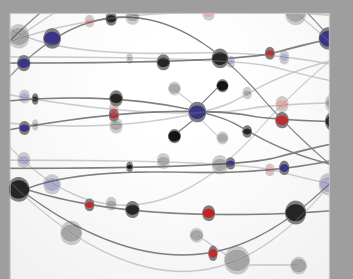

\section{Rotating \\ Machinery}

The Scientific World Journal

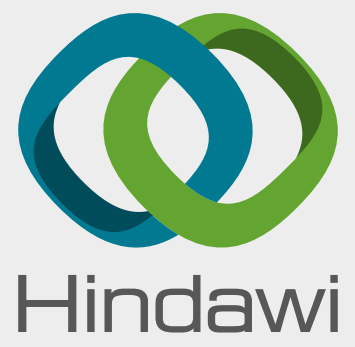

Submit your manuscripts at

www.hindawi.com
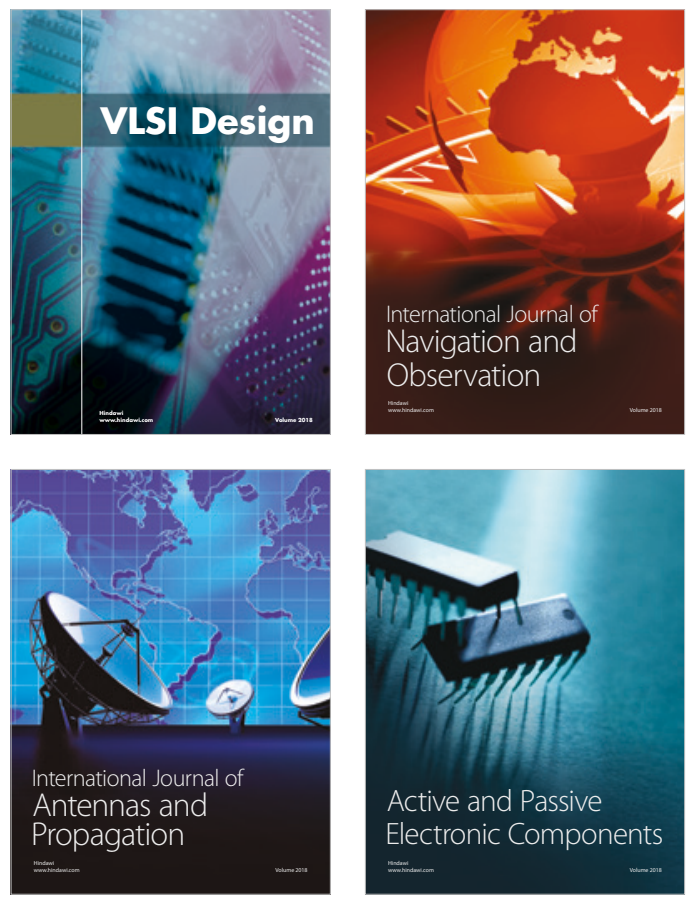
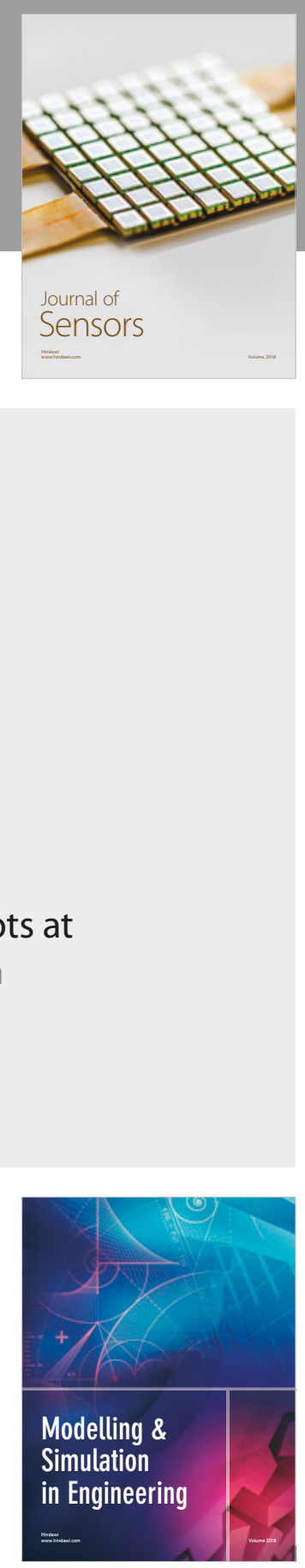

\section{Advances \\ Multimedia}
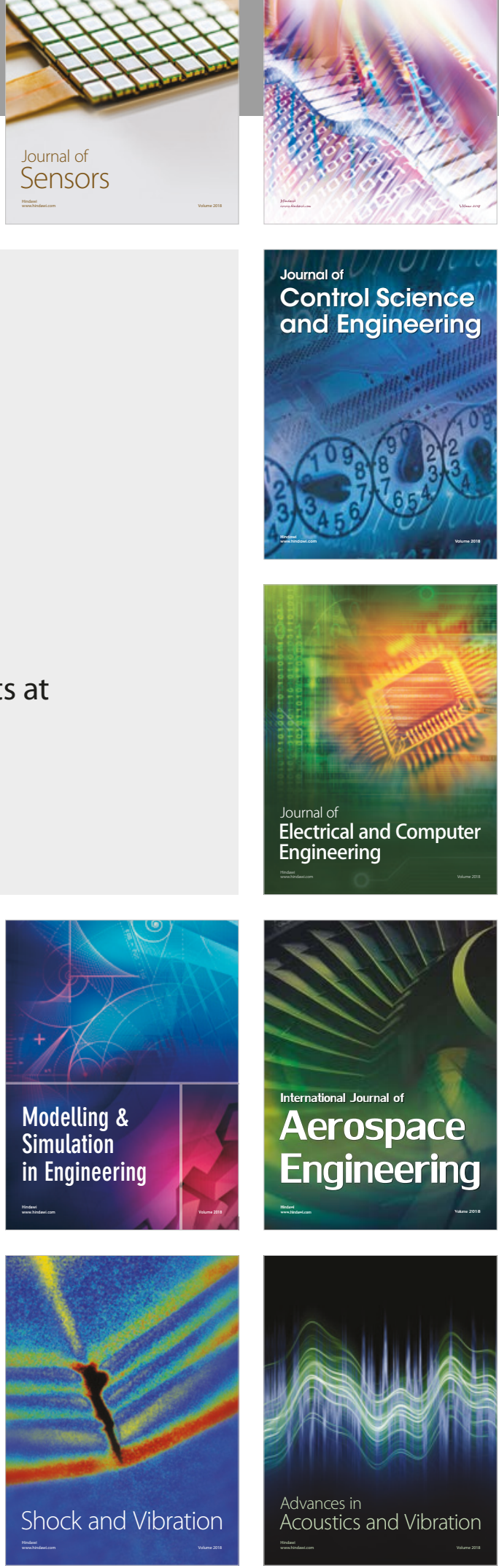